УДК 821.112.2 “ХІХ”

Бродська О.O.

кандидат філологічних наук, доцент, доцент кафедри практики німецької мови Інституту іноземних мов Дрогобицького державного педагогічного університету імені Івана Франка

\title{
ТЕМАТИЧНІ ТА ЖАНРОВО-СТИЛЬОВІ ОСОБЛИВОСТІ РАННЬОЇ ПРОЗИ АРТУРА ШНІЦЛЕРА
}

У статті висвітлені витоки поетики та ідейно-естетичні джерела ранньої прозової творчості Артура Шніилера (1862-1931). Розкриті основні художні принципи, які визначають жанрово-стильові особливості 
творів, мовностилістичні художні прийоми, тематично-смислові домінанти прози австрійського письменника.

Ключові слова: рання проза, новела, стиль, мотив, концептуальність, герой, образотворення.

B cтатье освещуень истоки поэтики и идейно-эстетические источники раннего прозачческого творчества Артура Шниилера (1862 1931). Раскрыты основные художественные принципы, которые определяют жанрово-стилевые особенности произведений, лингвостилистические художественные приемы, тематически-смысловые доминанты прозы австрийского писателя.

Ключевые слова: ранняя проза, новелла, стиль, мотив, концептуальность, герой, творение образов.

The article deals with the origins of the poetics of aesthetic and ideological sources of creativity Arthur Schnitzler (1862 - 1931). Revealed the basic artistic principles that define the genre and stylistic features of works of art lingvostilistik techniques, thematic meaning of the dominant prose of the Austrian writer.

Key words: an early prose, a short story, a style, a motive, conceptualization, a hero, image-creation.

Аналіз різножанрових творів А. Шніцлера відтінює концептуальну єдність як поетичних, так і прозових зразків 3 під його пера. Одним із творчих першоімпульсів був вірш «Любовна пісня балерини», яким А. Шніцлер дебютував у 1880 р. на сторінках мюнхенського журналу «Вільний кур'єр». Згодом він опублікував низку віршованих спроб і нарисів у виданнях «Німецький тижневик» та «На чарівному синьому Дунаї» (1886) [Schnitzler 2002: 915].

Витоки прозової творчості А. Шніцлера традиційно пов’язуються 3 1890 роком. Щоправда, перші проби його пера датовані десятиліттям 1870 - 1880 рр. Зіставна характеристика доробку 80-х рр. свідчить про те, що еволюція А. Шніцлера як прозаїка мала свою закономірну дикцію. На це вказав російський науковець І. Проклов [Проклов 2002:5], дослідник художньої спадщини австрійського письменника. Його думки про виділення трьох періодів потверджуються нашим аналізом. Йдеться про 
ранню прозу 80-х рр. і початку 90-х рр. (перший період). Вона включає перші «учнівські ескізи», низку «експериментальних новел» і перший етапний твір - новелу «Вмирання» (1894). Новелістика 90-х pp. і початку XX ст. охоплює другий період. На нього припадає розквіт імпресіоністичних змагань А. Шніцлера. Він завершується художньо довершеним твором - новелою «Лейтенант Густль» (1900). Тут відчутний так званий не лінеарний процес, що дозволяє зіставлення жанрових $\mathrm{i}$ мовно-стилістичних особливостей. Це характерно для прозових досягнень письменника, що окреслюють добу його творчих змагань упродовж 1911 1931 рр. (третій період). Саме в цей час були написані новели «Потрійне попередження» (1911), «Щоденник Редегонди» (1911), «Доктор Грейслер, курортний лікар» (1917), «Повернення Казанови» (1918), «Гра на світанку» (1926). Тут виразно проступають ознаки розчарування у художньому пізнанні ірраціональної складової людської психіки. Звідси - прагнення відобразити наслідки цієї складової. Ці штрихи - результат відчутного впливу робіт Зигмунда Фройда $(1856$ - 1939) на духовні змагання А. Шніцлера. Проте автор новели «Лейтенант Густль» проявив себе «проникливим знавием людської душі, вдумливим фактографом слова, якому вдалося художньо відтворити глибінь внутрішнього стану людини» [Matthias 1999].

Художня основа прози А. Шніцлера 80-х pp. надзвичайно різнорідна. Вона - свідчення активних пошуків власної творчої манери. Інтенсивні заняття медициною також знайшли своє відображення у творах цього періоду. Скажімо, зразки його набутку - «Весняна ніч у морзі» (1880), «Він чекає на Бога, вільного від обов’язків» (1886), «Спадок» (1889), «Мій друг Іпсилон» (1889), «Господар у домі» (1888), «Багатство» (1891), «Син» (1899) - підтвердження не лише його творчого поступу, а й наукового зацікавлення медициною. Більшість прозових зразків «новелістичних ескізів» i, власне, новел - це виявлення тем і мотивів, що 
цікавили А. Шніцлера. Ці дебютні твори, як правило, не часто були предметом літературознавчого аналізу. Щоправда, вони важливі, бо проливають світло на зацікавлення «письменника-початківця»; зокрема, йдеться про характерну особливість митця, що згодом стане однією із основних у спробах художньо осмислити «людське в людині», а також складники іiі психіки [Reik 1913]; [Wagner 2006]. Вона висвічує закладені в людині можливості, а саме на рівні свідомого і несвідомого у психічній структурі індивіда. А звідси - міру залежності людини від внутрішньої інтерпретації дійсності. «Неусвідомлене прагнення подолати обставини, за твердженням Р. Аллєрдіссена, а також невміння правильно, адекватно інтерпретувати дійсність стане в майбутньому однією з головних ознак шніилерівського імпресіоністичного героя» [Allerdissen 1985:123].

А. Шніцлер пов'язував свої психопоетичні досліди 3 темами творчості, психології, людини в мистецтві. Це засвідчують ескізи «Яка то мелодія!», «Він чекає на Бога, вільного від обов'язків», новели «Мій друг Іпсилон», «Багатство». Письменник у різних варіаціях змальовував трагедію людини творчої, яка не спроможна дати собі раду 3 особливостями і патологічними нахилами свого обдарування. А це нерідко спричиняло тяжіння до божевільного стану або ж призводило загибель, яку фіксував митець. Згодом А. Шніцлер розширив тематичні рамки, досягаючи розкутості, бажання по-новому пластично окреслити випробувані ходи. Тому він неодноразово звертався до поширеної у літературі психологічного зразка любовної тематики. Вона не розмивала межі між коханням і смертю. У цьому зв'язку примітні такі твори, як ескіз «Америка» (1887), новели «Спадок» (1889), «Інший» (1889), «Три еліксири» (1890), «Наречена» (1891), «Вмирання» (1894). Цей мотив, як справедливо зауважив У. Вайнцірль, «стане у більш пізній творчий період автора єдиним предметом зацікавлення» [Weinzierl 1998:123]. У названих творах новеліст робить наполегливі спроби природно, виправдано i 
переконливо узгодити любов з іï контрастом. Багато творів письменника яскраво ілюструють, за переконливим твердженням I. Мегели, перекладача творів А. Шніцлера українською мовою, «популярну в європейській літературі кіния XIX -початку XX cm. тему Ероса і Танатоса - смерті як антипода й вічного супутника кохання, як підвалин людського існування, протиборством між якими позначене все наше життя» [Мегела 2001:23]. Однак у взірцях кінця 80-х рр. ця тема, як правило, ще позбавлена меланхолійного, лірико-трагічного настрою, властивого зрілій творчості письменника. Він звертається швидше до «наслідків», що віддзеркалюють час «після любові». У цьому аспекті він близький до французьких натуралістів з їхніми вислідами не лише середовища, побуту, але й тілесної складової людського життя.

3 іншого боку, низка ескізів і новел 80-х рр. підтверджує той факт, що А. Шніцлер намагається «естетизувати $і$ суб'єктивізувати прагнення натуралізму до правди життя» [Mennemeier 1991:17]. У цьому процесі “згладжування” соціальних проблем позначився вплив суспільноморальної ситуації у тогочасному Відні, що абсолютно не сприяло відтворенню у літературних творах «всієї правди життя» [Weinzierl 1998]. А. Шніцлер як письменник не оминав соціальних проблем і гострих кутів. Здебільшого він звертався до змалювання особистого життя людини. В окремих новелах («Весняна ніч у морзі», «Він чекає на Бога, вільного від обов’язків», «Інший», «Син») цього періоду саме соціально-станові суперечності зумовлюють розвиток внутрішньої дії. Серед героїв ранньої прози А. Шніцлера виразно виділяються люди самотні, овдовілі, божевільні, потенційні і справжні самовбивці, гравці і злочинці. «Така галерея персонажів, - зазначає Г. Альтхаус, - прикрасила б творчість будь-якого натураліста» [Althaus 1976:6]. Беручи за предмет зображення суспільний статус, А. Шніцлер прагне проникнути під «покривало моралі, розкриваючи глибинні психічні мотиви людських вчинків» [Мегела 
2001:19]. У цьому прагненні митець проходить певну еволюцію. Якщо ранні ескізи «Яка то мелодія!», «Він чекає на Бога, вільного від обов'язків», «Америка», новели «Мій друг Іпсилон», «Спадок», «У театрі» вказують на те, що автору поки що не вдається розгорнути масштабне «дослідження» людської психіки, то новели «Багатство», «Син», «Наречена», а особливо новела «Вмирання» виявляють значний успіх Шніцлера-прозаїка на шляху художнього вивчення особистості. «Естетизація» натуралізму відбувалася таким чином, що письменник, маючи на меті опис життєвих процесів, використовував антинатуралістичні за своєю суттю художні засоби. У великій кількості прозових творів він послуговувався «прийомами іронічного дистаниіювання, “уявної” об'єктивності» [Aspetsberger 1970:417]. Примітний факт: у рамках ранньої прози А. Шніцлер апробував низку художніх прийомів. Вони згодом визначили його художній напрямок, що був суголосним імпресіоністичним постулатам. Поміж ними мали місце варіативність, певна універсальність. Все це творило гармонію між так званими осями, коли творець не маніпулював антропоцентричним сприйняттям дійсності, а малював іiі.

Так, новели «Спадок» і «Інший» були тим першим результатом, що дав дієвий акцент на життєтворчу основу, приміром, для творення внутрішнього монологу. Він увінчав імпресіоністичні підступи А. Шніцлера $з$ огляду на світосприйняття, об'єктивно відтворене в новелі «Лейтенант Густль».

Незважаючи на те, що твори А. Шніцлера 80-х pp. викликали неоднозначне враження, вони чітко визначали факт його творчого пошуку, прагнення митця зобразити плинність свідомості героїв за допомогою різних прийомів розкриття характеру, використання такого новельного засобу, як діалог. 
Проте діалогічна форма викладу не виключала Шніцлерових поетологічних експериментів щодо творення оригінальних композицій. Це виразно засвідчила новела “Вмирання”. Головна особливість цього твору полягає у принципі розвитку дії, що відбувається у винятково емоційнопсихічному плані. Йдеться про свідоме ускладнення конфліктної ситуації за рахунок загострення статичності віддзеркалення внутрішнього світу героїв. Тут важливо наголосити: саме новела «Вмирання» визначила рівень художніх пошуків, поглиблення інтелектуалізму, пожвавлення панорамного зображення найтонших нюансів почуттів, споглядальності, а також тієї активності, що була функціональною передумовою імпресіоністичного характеру. У згаданому творі автор вперше вдало змалював психічне життя людини у його невпинній течії. Це - перший етап великого експерименту Шніцлера-психолога у справі створення технічних прийомів для адекватної передачі свідомого і підсвідомого. Таким чином, «синтез “естетизованого натуралізму” ранньої прози новеліста зі спробою проникнення у глибини людської психіки» [Poser 1980:213] сприяв розвиткові імпресіоністичного письма митця. Окрім того, твір мав посутнє значення для розвитку австрійської літератури того часу, оскільки був показовим прикладом «подолання натуралізму». Це відповідало засадам Г. Бара, очільника гуртка «Молодий Відень».

У 90-х рр. А. Шніцлер остаточно уникає зображення похмурих сторін життя і занурюється у більш детальний аналіз людської душі. На противагу ранній прозі автора, новели 90-х рр. написані «на одну тему». Саме в цей час А. Шніцлер виступає як «співещь любові $i$ смерті» [Baumann 1965:27]. Однак при всій аналогічності ситуацій, стильових і композиційних прийомів, кожна новела цього періоду відрізняється властивою лише їй своєрідністю.

Художній світ прози А. Шніцлера 80-х pp. XIX ст. мав тенденцію, що містила стик, а радше - взаємопроникнення зображальних технік, 
тяжіння до оригінального письма. Хоча герої, яким симпатизує автор, i переживають великі страждання, зрештою їх обов’язково чекає моральна винагорода або ж певний порятунок. Складається враження, що А. Шніцлер ставить собі за мету досягнення «психотерапевтичного» заспокоєння читача, навіюючи йому ідею невідворотності справедливої розв’язки в будь-якій проблемній ситуації. Вона є викривленням картини реального, а не уявного оптимістичного буття. Письменник не обмежується культивуванням зображувальних прийомів, а формує текстову структуру, наповнюючи їі нерідко локальним колоритом.

\section{БІБЛІОГРАФІЯ}

Мегела 2001 - Мегела I. Ілюзія і реальність / Іван Мегела // А. Шніцлер. Передбачення долі. П’єси, оповідання / [пер. 3 нім. Івана Мегели, Бориса Грінченка, передм., прим. Івана Мегели, ред. Богдан Загайський]. - Чернівці : В-во газети «Молодий буковинець», 2001. C. 3-28.

Проклов 2002 - Проклов И.Н. Художественная проза Артура Шницлера рубежа XIX - XX-го веков : автореф. дис. на соискание уч. степени канд. филол. наук : 10.01.03 «Литература народов стран зарубежья» / И.Н. Проклов. - М., 2002. - 16 с.

Allerdissen 1985 - Allerdissen R. Arthur Schnitzler : Impressionistischer Rollenspiel und skeptischer Moralismus in seinen Erzählungen / Rolf Allerdissen. - Bonn: Bouvier, 1985. - 300 s.

Althaus 1976 - Althaus H. Zwischen Monarchie und Republik : Schnitzler, Kafka, Hofmannstahl, Musil / Horst Althaus. - München: Fink, 1976. $-188 \mathrm{~s}$.

Aspetsberger 1970 - Aspetsberger F. Wiener Dichtung der Jahrhundertwende. Beobachtungen $\mathrm{zu}$ Schnitzlers und Hofmannsthals Kunstformen / Friedbert Aspetsberger // Studi Germanici 8. - 1970. S. $410-451$. 
Baumann 1965 - Baumann G. Arthur Schnitzler : die Welt von Gestern eines Dichters von Morgen / Gerhart Baumann. - Frankfurt a. M.: Athenäum Verl., 1965. - 43 s.

Matthias 1999 - Matthias B. Masken des Lebens Gesichter des Todes. Zum Verhältnis von Tod und Darstellung im erzählerischen Werk Arthur Schnitzlers / Bettina Matthias. - Würzburg : Königshausen \& Neumann, 1999. $198 \mathrm{~s}$.

Poser 1980 - Poser H. Schnitzlers Erzählung «Sterben» - eine Diagnose ohne Therapie / Hans Poser // LfL, 1980. - S. 248 - 253.

Reik 1913 - Reik T. Arthur Schnitzler als Psychologe / Theodor Reik. Minden : J.C.C. Bruns, 1913. -302 s.

Schnitzler 2002 - Schnitzler A. Gesammelte Werke in drei Bänden. Band I : Erzählungen / [herausgegeben und mit einem Nachwort versehen von Hartmut Scheible]. - Patmos Verlag GmbH \& Co. KG Artemis \& Winkler Verlag, Düsseldorf und Zürich, 2002. - 927 s.

Wagner 2006 - Wagner R. Wie ein weites Land. Arthur Schnitzler und seine Zeit / Renate Wagner. - Wien : Amalthea Verlag, 2006. - 360 s.

Weinzierl 1998 - Weinzierl U. Arthur Schnitzler : Lieben, Träumen, Sterben / Ulrich Weinzierl. - Frankfurt am Main : Fischer-Taschenbuch-Verl., 1998. - 288 s. 